\title{
Study on integrated farming systems model development
}

\author{
M. S. U. Bhuiya ${ }^{1^{*}}$, M. M. Karim ${ }^{2}$ and S. M. A. Hossain ${ }^{2}$ \\ ${ }^{1}$ Department of Agronomy, Bangladesh Agricultural University, Mymensingh-2202, Bangladesh and ${ }^{2}$ LIFCHASA \\ Project, Department of Agronomy, Bangladesh Agricultural University, Mymensingh, Bangladesh \\ E-mail: sultanagron50@yahoo.com
}

\begin{abstract}
Study on Integrated Farming Systems Model Development was conducted by the Livelihood Improvement of Farming Community in Haor area through System approach Project of the Department of Agronomy, Bangladesh Agricultral University, Mymensigh worked in Purbo Tethulia village of Moahjganj upazilla, Netrakona district from April 2010 to June 2013 with the financial assistance from the National Agricultural Technology Project, SPGR subproject, Bangladesh Agricultural Council with the following objectives i. Increase productivity of field crops, vegetables, livestock and fishes in a household through the use of appropriate technogies and techniques devised/developed/ designed/refined by the farmers for ensuring household food security and nutritional upliftment and raising income ii. Diversify enterprises, mobilize resources and intensify farming and non farming activities for in situ employment generation iii. Conserve farm environment through efficient mobilization and management of natural resource for sustainable production sysyems iv. Develop human resoures for capacity building of the participants and improve their livelihood through system approach. Research programme was finalized in the Bench Mark Survey Workshop. Farmer selection for different research acivities was done as per plan for defferent five components. The crop and agroforestry component conducted experiments both in the homestead land and crop land. In the homestead area, year round vegetables were intervened through community trial for three years. Production of timber trees like mahogany, lambu and fruit trees like mango, guave, jujube, litchi, lemon papaya and jackfruit was also practiced. Timber trees are now at growing stage and among the fruit trees some like papaya, jujube and lemon are at bearing stage. African dhaincha was introduced around homestead fallow/waste land to protect homestead area from wave thrust and to produce biomass fuel. Field trials on rice, vegetables, spices and oil crops were conducted to intensify and diversify the cropping pattern and as well as to utilize the fallow/ waste land of the research site. Under livestock component, experiments were conducted on rearing of egg producing hen, duck, fattening of animals, milching cow, artificial insemination and chemical evaluation of available feedstuffs. A continuous vaccination programme against common diseases of poultry was maintained throughout the study period. Farmers' response was very positive towards the experimental results. In the fisheries component, experiment on cage culture in open water, perennial and seasonal pond culture, dry fish and pickle were conducted/done. Among the experiments cage culture in open water proved to be a promising technology and fish pickle was highly appreciated in panel test. For the rural hydrology and mechanization component four studies were conducted. The physico-chemical properties of farm land and homestead soils were determined. Additional application of sulphur and zinc fertilizers were found not required. Both the surface and groundwater characteristics were studied. The maximum flood water depth was found around $3.0 \mathrm{~m}$ at farm land. Irrigation facilities developed by installing a shallow tubewell (STW) resulted higher crop production and motivated farmers to install four new STWs by their own capital. All the households (462) of Purbo Tethulia were intervened from the project. The interventions were crop, vegetable, livestock, poultry and fish farming. It was observed that as the number of enterprises increased in the farming systems, the income also increased. The evidence also showed that the training of the beneficiaries increased their knowledge and skill.
\end{abstract}

Keywords: Integrated, Farming Systems, Model, Community trial, Diversification, Intensification

\section{Introduction}

Integrated farming as a concept and a principle involves two or more enterprises in a farm having strong cohesive and interactive relationship for production and consumption activities and in sharing and proper utilization of resources. Integrated farming has been considered as one of the most effective means of mobilizing resources in subsistent farms and addressing issues of degraded soil, depleted water resource, deforestation, shortage of rural biomass energy along with the risk of natural calamities, drought, cyclone, salinity, etc. and thereby raising productivity of land and man in a sustainable way which ultimately helps in alleviating/ eliminating poverty and improving the quality of life and overall welfare of the farming community. The integrated farming is the characteristics of subsistent agriculture and age old practice all over the world especially for the developing countries with small holdings. But unfortunately very little efforts have been made to improve/develop this practice in a holistic way perhaps because of lack of systems approach for development of agriculture and the existing uncoordinated, non- 
integrated and discipline based extension activities. For constructing efficient farming systems/integrated farming systems the approach of development must aim at the household level to address the problems of the farming community with interdisciplinary zeal and spirit. Mixed farming is the main feature of Bangladesh agriculture with an average of 0.81 ha land, 1.60 cattle head, 1.03 goat-sheep and 5.33 poultry per farm to sustain 5.33 family members. With these very limited resources it is very difficult to fulfill the basic and welfare needs. A large share of population (about 48\%) lives below poverty (intake less than $2122 \mathrm{Kcal} / \mathrm{capita} /$ day) of which the population below absolute poverty line (intake less than $1805 \mathrm{Kcal} / \mathrm{capita} / \mathrm{day}$ ) is about $27 \%$ (BBS, 2010). The small and landless farmers generally along with low physical resource base have an extremely low level of human capital in terms of education, knowledge and health with which they work, they suffer chronic indebtedness, lack accessibility to institutional credit and inputs, receive inadequate extension support and are unable to use services of other delivery systems. They are struggling for subsistence. In spite of resource constraints, it has been recognized that the farmers have a great richness of knowledge about the resources they are experimenters, risk takers, innovators and intensifiers, diversifiers and practitioners of great common sense, who have remarkable capacities to adapt, to change and constraints to evolve their techniques over time. Proper tuning of these resources may accelerate the land and man productivity in the farming community. Bangladesh agriculture with its 9.23 million hectare (BBS, 2010) cropland with 191\% cropping intensity (BBS, 2011) is not able to cover 150 million people at present level of technology. The agriculture providing occupation to $51 \%$ of the households and generates employment for 63 percent of the total labour force. In order to live a decent life technological break through is a must for Bangladesh agriculture to exploit and mobilize the very scarce resources of the farm family i.e. the land, the people, the animal and other natural resources. As already indicated integrated farming is one of the key approaches to address such resource poor farm holdings with or without crop. Experimental findings clearly reveal that slight intervention can efficiently integrate enterprises and ease the productivity of the systems and help in ensuring food security, upgrading nutritional status, utilizing of organic waste and eliminating poverty (FSES, 1996).

It shows that under present farm resources and farm environments in Bangladesh, there is an excellent scope for improving productivity, ensuring household food security and upgrading nutritional status and overall welfare of the farmers through diversification of enterprises, mobilization of resources and intensification of farm activities. The study was undertaken in Purbo Tethulia, a village of Dingaputa haor with the following objesctives.

i. to increase productivity of field crops, vegetable, livestock and fishes in a household through the use of appropriate technologies and techniques devised/developed/designed/refined by the farmers for ensuring household food security and nutritional upliftment and raising income

ii. to diversify enterprises, mobilize resources and intensify farming and non farming activities for in situ employment generation

iii. to conserve farm environment through efficient mobilization and management of natural resources for sustainable production systems

iv. to develop human resources for capacity building of the participants and improve their livelihood through system approach.

\section{Materials and Methods}

Purba Tethulia village falls in the Sylhet Basin Agro-ecological Region (AEZ 21). This region is called haor. The word haor is a corrupt from the Sanskrit word Sagar which means sea. The haor is characterized by a central depression or basin, very large and deep flood plains with no natural surface drainage. The haor receives extensive surface water during the monsoon rains, when water enters. Bangladesh from the hills of India forming huge lakes or inland seas and flooding large areas with waters averaging 2-5 $\mathrm{m}$ for seven months of every year. The Proposed Research Site Purba Tethulia is not an exception to all those characteristics. 
Village: Purbo Tethulia (Dingaputa Haor) Upazila: Mohanganj District: Netrakona

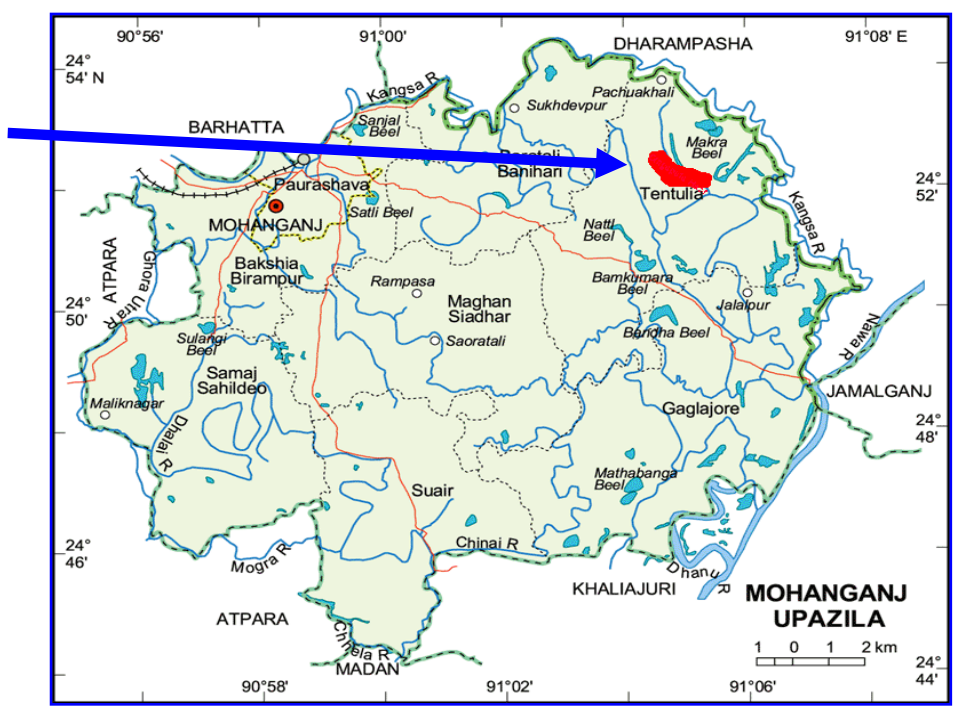

\section{Physical characteristics}

The research site geographically is located at $28^{\circ} 57^{\prime} \mathrm{N}$ latitude and $90^{\circ} 50^{\prime} \mathrm{E}$ longitude. The site belongs to the Non-calcareous Dark Gray Floodplain soil under the Sylhet Basin of AEZ 21 (UNDP and FAO, 1988). In Purbo Tethulia, about $70 \%$ of the area is medium low land and the remaining $30 \%$ is low land (LIFCHASA, 2010). The land with medium low topography remains waterlogged for 5-6 months (May to October) during monsoon season is flooded with maximum of $90-180 \mathrm{~cm}$ water. On the other hand, land with low topography remains waterlogged for 6-7 months (May to November) during monsoon season and is flooded with water height of 180 to $275 \mathrm{~cm}$. The soil in Purbo Tethulia is clayey in texture with dark grey colour. The soil in the area is mostly acidic in nature $(\mathrm{pH} \mathrm{6.5)} \mathrm{with} \mathrm{high} \mathrm{organic} \mathrm{matter} \mathrm{content}$ (4.05\%). Status of $\mathrm{P}, \mathrm{CEC}$ was medium and $\mathrm{K}$ status was low.

\section{Biological characteristics}

Boro rice was found as the most dominant crop in the Research Site with coverage of 295.68 ha of the total cultivated area. Chili was the second dominant crop (4.05 ha) followed by black gram (3.52 ha). Other minor crops were found to grow in the Site included coriander $(0.65 \mathrm{ha})$, radish $(0.61 \mathrm{ha})$, potato (0.40 ha), onion (0.16 ha), stem amaranth (0.12ha), brinjal $(0.018 \mathrm{ha})$ and garlic (0.04). Only two high yielding varieties of Boro rice namely BRRI dhan28 and BRRI dhan29 were grown by the farmers with higher area coverage. BRRI dhan28 was preferred by the farmers probably because of its shorter growth duration, which might help farmers to avoid crop damage due to early flash flood. Neither any local variety nor any hybrid variety of Boro rice was found to grow in the Research Site. The area is scatteredly covered by various timber and fruit tree species like raintree, mango, mahogony, guava, hijal, karoch, etc. The animal breeds and the chicken breeds were local. There were few ponds with traditional fish culture with major carps like katla, carpio, mrigel, etc. The highest number of families (279) used to get fish from open water and 199 families used to buy fish from the market. Culture fish is consumed by only six households. On the other hand 22 households used to get fish from all the sources.

\section{General implementation methodology of LIFCHASA}

For implementing the LIFCHASA Project the general methodology of the Farming Systems and Environmental Studies (FSES) was followed. The methodology was developed based upon the warming experiences over 1-5 years on cropping systems and farming systems research under the leadership of the Bangladesh Agricultural Research Council (BARC). The FSR Methodology Guideline of BARC was also consulted. The schematic presentation of General Implementation Methodology can be seen in Fig. 1. 


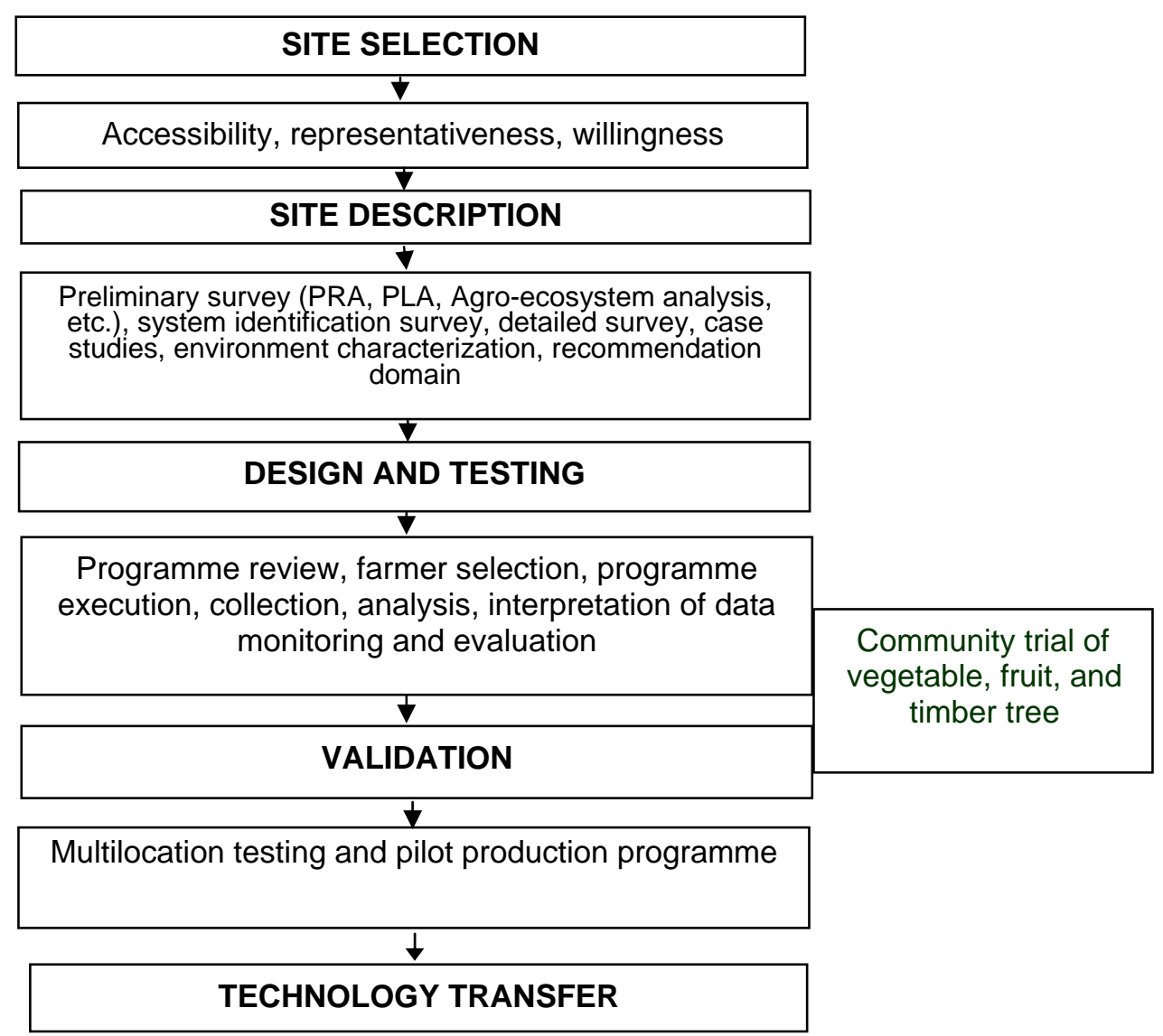

Fig. 1. Schematic representation of General Implementation Methodology developed by FSES (2002)

This modification was necessary because the LIFCHASA Project started functioning viz., from April 2010, when there was no scope for growing field crops as the Dingaputa haor was inundated with flash flood which occurred on 25 March 2010. The modification of methodological steps/processes found working and given an innovative dimension in FSR methodology in addressing livelihood improvement of all categories of farmers in the community in field of employment generation, food and nutrition security and income generation for the women.

\section{Implementation unit and its procedures for implementation}

The LIFCHASA was the implementation unit for administration and management. The organogram of LIFCHASA is given in Fig. 2. The organogram is self explanatory in respect of LIFCHASA implementation procedure. Site working group was added to it as a new inclusion to accommodate an effective site level of participation of GOs, NGOs and farmers for planning and implementation of LIFCHASA activities.

\section{Planning of LIFCHASA activities}

Planning at the site level: Planning was initiated at the site level by the Site Working Group as mentioned above and Figure 2 and reviewed the progress from time to time. The Site Coordinator acted as the Convener of the site level working group.

Planning and review at BAU: The proposed plan was discussed, refined and finalized at the Programme Development Workshop attending researchers from BAU, NARS institutes and GOs and NGO representatives (Fig. 2) at BAU once a year and reviewed the progress of LIFCHASA. . 


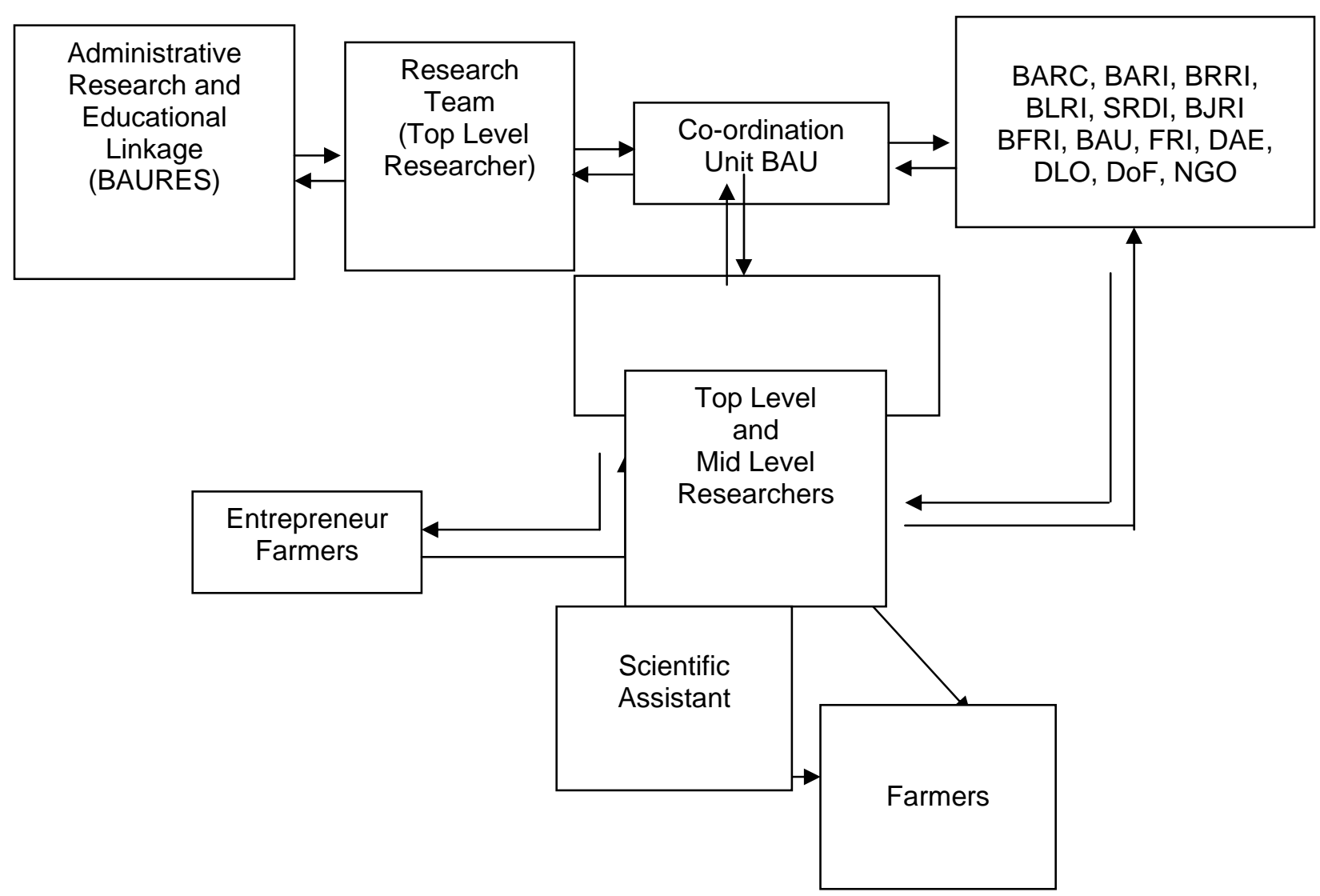

Fig. 2. Implementing Organogram of the Livelihood Improvement of Farming Community in Haor Area through System Approach

\section{Farmer selection for integrated farming model development}

Farmer selection for the integrated farming model development was done through identification of farmers, their farm sizes and farming systems. Out of 462, 232 farming households were found having stable and sustainable farming systems, the rest of households (230) appeared to have most volatile farming enterprises and the system may not continue for long time. On system basis classification in each system the number of farmers was less than 10 and they were dropped from the study. Thus 25 farmers were selected based on farmer category and farming systems for intervention of integrated farming development in addressing livelihood improvemt. Sultan Miah one of them.

\section{Name of farmer $\quad: \quad$ Sultan Mia}

1. Farming Systems

\begin{tabular}{|l|l|}
\hline Before intervention & After intervention \\
\hline $\begin{array}{l}\text { Crop -Livestock-Poultry- Fish } \\
\text { catching-Homestead agroforesty }\end{array}$ & $\begin{array}{l}\text { Crop- Livestock- Poultry -Fish catching -Fish culture- } \\
\text { Homestead agroforestry-Homestead vegetable }\end{array}$ \\
\hline
\end{tabular}


2. Human resource status of the household

\begin{tabular}{|c|c|c|c|c|}
\hline $\begin{array}{l}\text { Relation with } \\
\text { family head }\end{array}$ & $\begin{array}{c}\text { Age } \\
\text { (Year) }\end{array}$ & $\begin{array}{l}\text { Marital } \\
\text { status }\end{array}$ & Occupation & Human resource development \\
\hline Himself & 35 & Unmarried & Farming & \multirow{7}{*}{$\begin{array}{l}\text { - Training of project beneficiaries for } \\
\text { skill development on integrated } \\
\text { farming } \\
\text { - Training on Boro rice cultivation } \\
\text { - Training on winter vegetable } \\
\text { cultivation } \\
\text { - Training on poultry and duck rearing }\end{array}$} \\
\hline Father & 65 & Married & Farming & \\
\hline Mother & 55 & Married & Housewife & \\
\hline Brother & 14 & Unmarried & Farming & \\
\hline Brother & 7 & Unmarried & Student & \\
\hline Sister & 18 & Unmarried & Unemployed & \\
\hline Sister & 16 & Unmarried & Unemployed & \\
\hline
\end{tabular}

\section{Technology dissemination}

The technologies of the LIFCHASA were disseminated through participating farmers, non-participating farmers and government extension departments. The LIFCHASA received feedback from technology users for further refinement them more adaptively.

\section{Methodology of integrated farming systems model development}

The 'physical' or 'Iconic' model is also called descriptive model. These types of models are needed for guiding extrapolation to similar environment. These models can be continuously refined depending upon the physical, biological, socio-economic, political and other factors and also the resource-base of the farmers (Hossain et al,. 1993). Since principle of integration is adopted, these models are cost-effective and risk-aversive. A coping mechanism for integrated farm development is shown in Fig. 3.

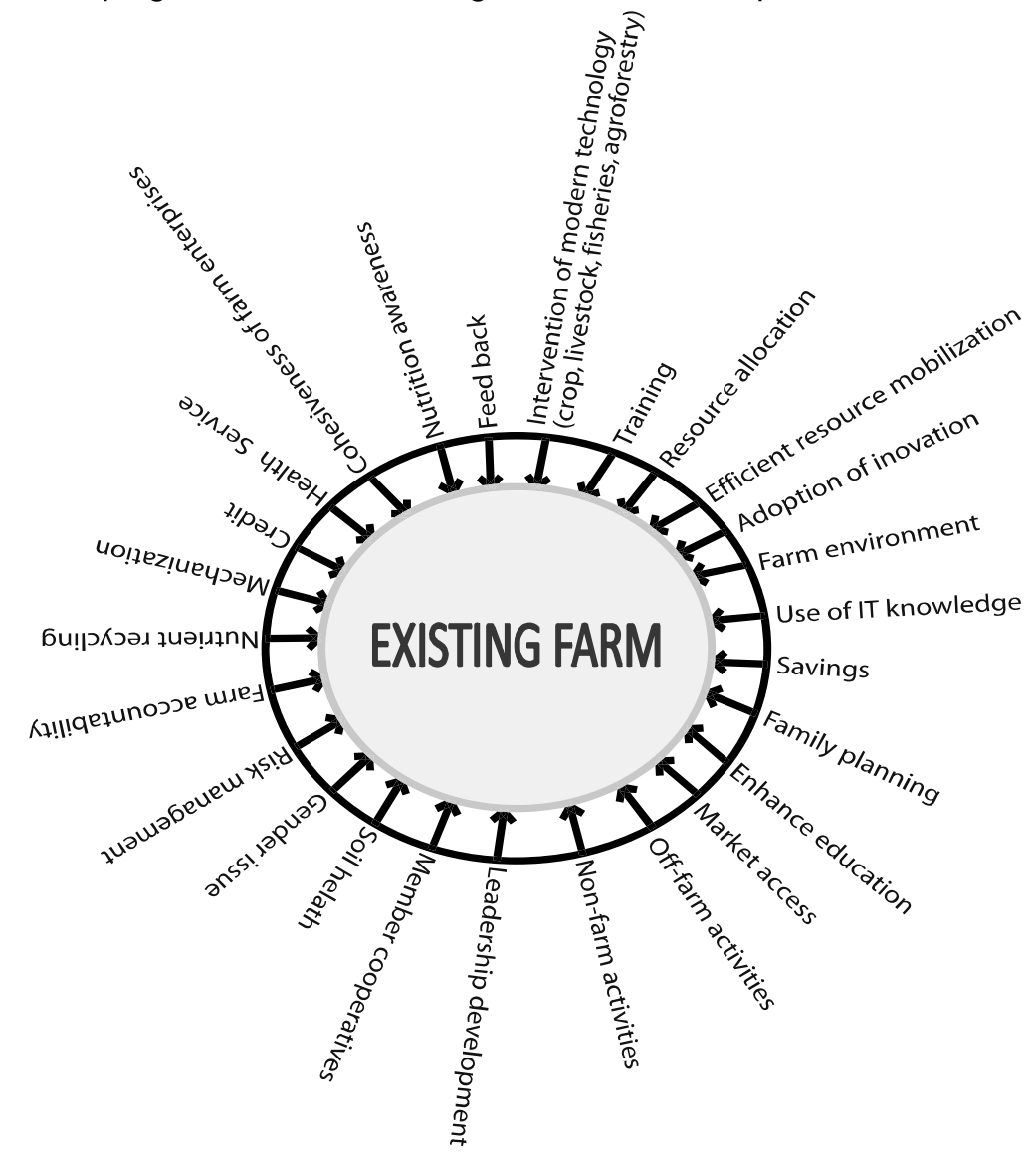

Fig. 3. Coping mechanism for integrated farm development (FSES, 2001) 
Important assumptions

Integrated farming systems were tried based on the following important assumptions:

\section{Concept}

i. Each farming household will be able to maintain its family members by judicial arrangement, mobilization and management of its resources irrespective of farm sizes.

ii. Diversification of enterprises in the farm will raise the productivity of land, labour and improve the quality of living in subsistence farms and landless households.

iii. Productivity of crop, livestock, fishery and agroforestry can be raised to a desirable level by mobilizing existing farm resources and available technology.

iv. The farmers' ingenuity and interest will accelerate to build up productive farming systems.

v. The existing farming systems will be refined with least disturbances. The change of the systems will be gradual not sudden.

vi. Ecological farming through integration of sub-systems will protect farm environment for sustaining agriculture.

vii. Development of small scale entrepreneurship is possible with the interested farmers - a step for commercialization and agribusiness.

\section{Context}

i. Farmers are ready to accept environment specific and need oriented innovations for improving the livelihood.

ii. Technologies generated by the research institutes/organizations need refinement with the participation farmers in farm environment for adoption/adaption.

\section{Environment}

i. The environment consists of human, physical, biological, social and economic elements.

ii. Farmers' target is continuously moving with changing environment.

iii. Environmental friendly farming practices will reduce the environmental degradation.

\section{Resource}

Resource includes human, physical, biological, social and economic elements. These resources can be improved through manipulation by adopting suitable means e.g. human resource can be upgraded through training.

\section{Input}

Input may be materials or non-materials (knowledge/information/technology).

\section{Management}

Farmers' management may be improved through participation and intervention.

\section{Output}

The output will be 1. cash and 2. kind (Information, employment, off-farm activities and cottage industry support). The cash and kind will generate the following:

Kind - food, shelter, fuel, manure, industrial and transport material and aesthetic material.

Cash - shelter, clothing, education, health and sanitation, investment, input, food and daily essential, recreation, social function and status, savings and aesthetic need. 
Intervention given by LIFCHASA

Crop production systems

Homestead production systems

Winter vegetable 2010

Bottle gourd (cv. BARI lau-1) and Country bean (cv. BARI sheem-2)

\section{Summer vegetable 2011}

Lady's finger (cv. Hi-soft), Indian spinach (cv. Puishak shabuj), snake gourd (cv. Kobra), sweet gourd (cv. Shotabdi), ash gourd (cv. Super star), and yard long bean (cv. Kegornato).

Winter vegetable 2011

Bottle gourd (cv. Martina) and Country bean (cv. Knoldog).

\section{Summer vegetable 2012}

Lady's finger (cv. Arka anamika), Indian spinach (cv. Boropata), snake gourd (cv. Jhumlong), ash gourd (cv. Super star).

\section{Winter vegetable 2012}

Bottle gourd (cv. Martina) and Country bean (cv. Knoldog)

\section{Fruit and vegetable}

Mango (Amropaly), guava (cv. Madhury), lemon (cv. Baromashi), jujube (cv. BAU Kul/ Apple Kul), papaya (cv. Kashimpuri, Red lady), drum stick

\section{Timber}

Mahogani and lambu.

\section{African dhaincha.}

\section{Field crop production systems}

Potato-Boro rice- Dhaincha (Under seasonal flooding)

Mustard-Boro rice- Dhaincha (Under seasonal flooding)

Radish-Boro rice-Fallow (Under seasonal flooding)

Cabbage-Lady's finger- Fallow (Under seasonal flooding)

Cauliflower-Indian spinach - Fallow (Under seasonal flooding)

Tomato-Stem amaranth-Fallow (Under seasonal flooding)

\section{Livestock production systems}

Duck (Br. Deshi).

\section{Fisheries production systems}

Cage culture

\section{Results and Discussion}

The component technologies used for intervention according to farmers' felt need, problem solving, resource potential and management. However the decision was taken by the farmers. The impact of LIFCHASA interventions was evaluated on the basis of bio-economic performance and improvement of social status. 


\section{Biological performance}

The biological performance was measured in terms of productivity of crop, livestock, fishes and biomass fuel including timber. The crop data were collected through seasonal (four periodly) monitoring while those of livestock, fisheries and agroforestry were collected through six periodly monitoring. The homestead production data were collected through yearly monitoring. The collected data were analyzed on yearly basis and the average of all years' data was presented in the respective models component wise.

\section{Economic performance}

Economic performance was measured with respect to land holding, labour utilization, gender participation, labour potentiality, labour productivity and energy status.

The potential labour farm ${ }^{-1}$ was calculated as 22.5 days male ${ }^{-1}$ adult multiplied by total family members. In calculating the potential female and child labour the following conversion rate was followed.

1 adult male $=1.5$ adult female $=2$ children (12-18 years).

In calculating the labour productivity of a model the following formula was used

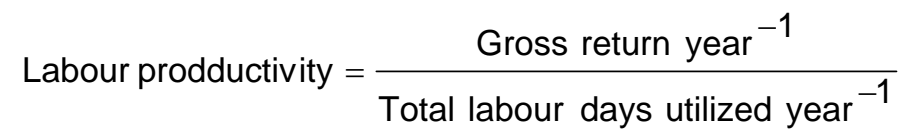

The economic analysis of various components of the model was done on the basis of local market price of inputs and products. The gross margin was calculated by deducting total variable cost from gross return. The cost-benefit ratio was calculated on the basis of total annual gross return divided by total annual cost of the farmer.

The contribution of each component was calculated as percentage of total Tk. of a farm (model) year ${ }^{-1}$. The capita ${ }^{-1}$ labour productivity was calculated as per value of total production divided by total family members of age 12 and above. The contribution in resource was calculated as per money value of inputs and cash investment total.

\section{Socioeconomic change}

Social change was evaluated on the basis of improvement in nutrition, housing, clothing, medicine, education, communication, leadership and saving.

\section{Land resource}

\begin{tabular}{|l|c|c|}
\hline Land category & $\begin{array}{c}\text { Before intervention } \\
\text { Area (Decimal) }\end{array}$ & $\begin{array}{c}\text { After intervention } \\
\text { Area (Decimal) }\end{array}$ \\
\hline Homestead area & 10 & 10 \\
\hline Crop land (own) & 100 & 100 \\
\hline Crop land (rented in) & 100 & 200 \\
\hline Pond & - & - \\
\hline Total land & $\mathbf{2 1 0}$ & $\mathbf{3 1 0}$ \\
\hline
\end{tabular}

Type of cropping pattern

\begin{tabular}{|l|l|}
\hline Before intervention & After intervention \\
\hline \multirow{3}{*}{$\begin{array}{l}\text { Boro rice-Fallow- Fallow } \\
\text { Under seasonal flooding). }\end{array}$} & Boro rice -Fallow- Fallow (Under seasonal flooding). \\
\cline { 2 - 2 } & Potato-Boro rice- Dhaincha (Under seasonal flooding). \\
\cline { 2 - 2 } & Mustard-Boro rice- Dhaincha (Under seasonal flooding). \\
\cline { 2 - 2 } & Radish-Boro rice-Fallow (Under seasonal flooding). \\
\cline { 2 - 2 } & Cabbage-Lady's finger- Fallow (Under seasonal flooding). \\
\cline { 2 - 2 } & Cauliflower-Indian spinach - Fallow (Under seasonal flooding). \\
\cline { 2 - 2 } & Tomato-Stem amaranth-Fallow (Under seasonal flooding). \\
\hline
\end{tabular}


Economic analysis

\begin{tabular}{|l|c|c|}
\hline Item & Before intervention (Tk) & After intervention (Tk) \\
\hline Total cost & 37450 & 124534 \\
\hline Gross return & 71445 & 310373 \\
\hline Gross margin & 33995 & 185839 \\
\hline
\end{tabular}

Homestead and agroforestry plantation

\begin{tabular}{|l|c|c|}
\hline Type of plant & Before intervention & After intervention \\
\hline Total number of timber plant & 5 & 12 \\
\hline Total number of fruit tree & 3 & 7 \\
\hline
\end{tabular}

\section{Economic analysis}

\begin{tabular}{|l|c|c|}
\hline Item & Before intervention (Tk) & After intervention (Tk) \\
\hline Total cost & 185 & 1320 \\
\hline Gross return & 46824 & 56977 \\
\hline Gross margin & 46639 & 55657 \\
\hline
\end{tabular}

\section{Livestock systems}

\begin{tabular}{|l|c|c|}
\hline Item & Before intervention (No.) & After intervention (No.) \\
\hline Hen & 3 & 5 \\
\hline Chick & - & 3 \\
\hline Duck & 14 & 8 \\
\hline Cow & 2 & 4 \\
\hline
\end{tabular}

Economic analysis

\begin{tabular}{|l|c|c|}
\hline Item & Before intervention (Tk) & After intervention (Tk) \\
\hline Total cost & 24500 & 64520 \\
\hline Gross return & 48227 & 106329 \\
\hline Gross margin & 23727 & 41809 \\
\hline
\end{tabular}

Fisheries systems

\begin{tabular}{|l|l|l|}
\hline Item & Before intervention & After intervention \\
\hline Catch fish & Fish catching & Fish catching \\
\hline Culture fish & \multicolumn{1}{|c|}{-} & Cage culture \\
\hline
\end{tabular}

Economic analysis

\begin{tabular}{|l|c|c|}
\hline Item & Before intervention (Tk) & After intervention (Tk) \\
\hline Total cost & 12510 & 22800 \\
\hline Gross return & 27543 & 43587 \\
\hline Gross margin & 15033 & 20787 \\
\hline
\end{tabular}

\section{Housing pattern}

\begin{tabular}{|l|l|l|}
\hline Type of house & Before intervention & After intervention \\
\hline Bedroom & Tin roofed and bamboo fenced & Tin roofed and tin fenced \\
\hline Kitchen & Thatched & Tin roofed and bamboo fenced \\
\hline Cow shed & Thatched & Thatched \\
\hline
\end{tabular}


Economic analysis of the integrated farm

\begin{tabular}{|l|c|c|}
\hline Item & Before intervention (Tk) & After intervention (Tk) \\
\hline Total cost & 74645 & 213174 \\
\hline Gross return & 194039 & 517266 \\
\hline Gross margin & 119394 & 304092 \\
\hline
\end{tabular}

Food security and nutritional status

Number of meal taken per day (Monthly basis)

\begin{tabular}{|l|c|c|}
\hline \multirow{2}{*}{ Period } & \multicolumn{2}{|c|}{ Number of meal taken per day } \\
\cline { 2 - 3 } & Before intervention & After intervention \\
\hline $\begin{array}{l}\text { Normal period } \\
\text { Boishak - Ashwin (April-October) }\end{array}$ & 3 & 3 \\
\hline $\begin{array}{l}\text { Crisis period } \\
\text { Kartik - Chaitro(November -March) }\end{array}$ & 2 & 3 \\
\hline
\end{tabular}

\section{Labour productivity}

\begin{tabular}{|c|c|}
\hline Before intervention (Tk) & After intervention (Tk) \\
\hline 146.18 & 179.48 \\
\hline
\end{tabular}

\section{Socioeconomic impact}

Rented in 100 decimals of crop land, Housing pattern has been changed and repaid loan amount of Tk. 47000 on Association for Social Advancement (ASA) and food security improved.

\section{Conclusion}

From the study it is distinctly clear that the efficiency of marginal and small farms was improved in agro economic productivity with the increase of number of farming enterprises intervened in respective of farm sizes. The marginal and small farmers appeared to be the most efficient performers in the integration and arrangement of farming enterprises. This was followed by landless and medium farms. The gross margin for marginal and small, landless and medium increased by $84 \%, 89 \%$ and $50 \%$, respectively involving the enterprises like crop and agroforestry, livestock and fisheries. The labour productivity also increased by $18.24 \%, 34.24 \%, 35.14 \%$ in landless, marginal and small and medium farms, respectively. The integrated farming also generated more employment irrespective of male and female labour. Food security was improved due to integration farming enterprises. Integrated farming also improved farm environment by application of compost through its production and preservation of kitchen waste by polythene pit method.

- Crop technologies refined/developed in the homestead and in the crop field needs further upscaling.

- The findings of livestock viz., cross bred and hybrid hen and duck were very promising for dissemination in the haor area

- Beef fattening was very successful in the Research Site and need further upscaling in the haor area.

- Performance of case culture of tilapia was excellent. This technology needs to dissemination in the haor.

- Pond culture of fishes performed well and this technology needs extension.

- The technology generated on irrigation can successfully be extended in the haor area. 


\section{References}

BBS (Bangladsh Bureau of Statistics). 2010. Yearbook of Agricultural Statistics of Bangladesh. Ministry of Planning. Govt. of the People's Repablic of Bangladesh, Dhaka. pp. 137.

BBS (Bangladsh Bureau of Statistics). 2011. Yearbook of Agricultural Statistics of Bangladesh. Ministry of Planning. Govt. of the People's Repablic of Bangladesh, Dhaka. pp. 136-140.

FSES, 2002. Studies on Integrated farming 1999-2001. In: Fact Searching and Intervention Farming System and Env. Stud. Bangladesh Agril. Univ., Mymensingh.

FSES, 2001. Studies on Integrated farming 1999-2001. In: Fact Searching and Intervention Farming System and Env. Stud. Bangladesh Agril. Univ., Mymensingh.

FSES. 1996. Fact Searching and Intervention 1991-95. Farming Systems and Environmental Studies, BAU, Mymensingh.

Hossain, S.M.A., Alam, M.M.B.A. and Kashem, A.M. 1993. Agro-economic productivity of potatos in the Potato-Sweet potato-Fallow pattern. Frmg. Syst. Res. And Dev. Prog., Research activities 1989-90. Bangladesh Agril. Univ., Mymensingh. pp.9-12.

LIFCHASA (Livelihood Improvement of Farming Community in Haor Area through System Approach). 2010. Bench Mark Survey Report. Dept. Agron., Bangladesh Agril. Univ., Mymensingh.

UNDP (United Nations Development Programme) and FAO (Food and Agriculture Organization). 1988. Land Resources Appraisal of Bangladesh for Agricultural Development. Report 2. Agro-ecological Regions of Bangladesh. United Nations Development Programme and Food and Agriculture Organization. New Airport Road, Farmgate, Dhaka. pp. 212-221. 